\title{
Factors Influencing Online Shoppers to Shop at Marketplace or Website: A Qualitative Approach
}

\author{
Syafeqah Nurul Marzuki*, Ida Md Yasin \\ Putra Business School, Malaysia \\ *Corresponding author's email: syafeqahmarzuki [AT] gmail.com
}

\begin{abstract}
The Internet allows people to purchase without visiting an actual store. Many retail businesses use electronic commerce (e-commerce) operations to make it easy to sell goods or services to consumers over the Internet. Research is carried out on the process of e-commerce adoption, in particular on business to consumer (B2C). In addition, the advent of digital information platforms that enable the consumer to consumer $(C 2 C)$ changes the way service ecosystems generate value for digital transformation and produce value for it. This paper, therefore, explores online shopping aspects and understands the influence on online consumers shopping on the marketplace or website. Qualitative research shows the elements encouraging online buyers to shop on the marketplace or the website by analyzing data obtained through interviews with 15 participants. The findings of this study indicate the main factors influencing online shoppers to shop at marketplace or website are 1) online convenience, 2) affordability, 3) information quality, 4) evaluation for options, 5) promotions, 6) electronic word of mouth (eWOM), 7) trusted and secure, and 8) value added service. Businesses can take advantage of the results to understand emerging markets deeper. This trend provides business managers with the basis to design consumer attraction approaches and increase the performance of online shopping services. The findings of this study can allow marketers to understand consumers' intents and develop long-term partnerships between businesses and consumers. The potential for internet purchasing, especially in emerging markets, is growing increasingly tempting. This analysis is consistent with online shopping trends.
\end{abstract}

Keywords--- Marketplace, e-marketplace, e-commerce, online website, online shopping, business-to-consumer (B2C), consumer-to-consumer $(\mathrm{C} 2 \mathrm{C})$

\section{INTRODUCTION}

Thinking of ways to digitalize a business is a must starting in 2020, especially when a pandemic hits the world. As this pandemic began, more and more people are spending their time on smartphones, and business owners need to reach out to consumers by doing their digital marketing. The Movement Control Order (MCO) lockdown in 2020 instructed enterprises and businesses that were considered non-essential to halt operations. One crucial point to notice is that e-commerce in Malaysia is considered an essential service.

E-commerce has grown in response to the increased use of the internet. E-commerce sales worldwide reached 4.28 trillion US dollars in 2020, with revenues expected to reach 5.4 trillion US dollars in 2022 and amongst the most popular internet hobbies in the world is shopping. (Chevalier, 2021). The Gross Merchandise Value (GMV) of Malaysia's e-commerce industry was estimated to be around six billion US dollars in 2020, with a forecast of 13 billion US dollars by 2025 (Müller, 2021). Müller added that e-commerce has been on the increase in Malaysia for quite some time, and it is not anticipated to slow down soon. E-commerce merchants must take the necessary steps to adopt this platform into their marketing plans to display, promote, and sell products or services locally and internationally via the internet business.

Malaysians have spent more time available on the internet and are now ready to buy products online. Indeed, two-thirds of them are better at purchasing online, as indicated in a poll in September 2020 (Jaafar, 2020). Data from the German online statistics platform Statista shows that the Malaysian e-commerce industry produced US $\$ 3.68$ billion (RM15.2 billion) in revenue for 2019, with a yearly market rise expected to hit $11.8 \%$ by 2023. In Malaysia, Shopee and Lazada, marketplace platforms, aim to pioneer the local online shopping room. Shopee made significant improvements with the highest user downloads of its mobile app.

Every online business needs one or more platforms for the consumers to purchase. There are several options to sell the products online, such as creating their e-commerce website or selling their products on marketplaces such as Shopee, Lazada, Zalora and many more. Buyers are searching for remarkable experiences through these digital and physical touch points with brands as the technology ease the buyers' shopping journey. Despite the availability of marketplaces or the brand's website for online shopping, some individuals choose to buy from one of the platforms. Concerning consumers in 
Malaysia, this study will investigate factors influencing them to purchase through e-commerce websites or marketplaces. One of every business's objectives is to boost income and reach out to as many people as possible. Exposing them to the aspects that influence consumers' decisions to buy from an e-commerce website or a marketplace may aid them in deciding which selling platform to employ and attaining their objectives. Other than that, this research will give an outlook to the ecommerce or marketplace providers on buyers' needs.

\section{LITERATURE REVIEW}

\subsection{E-commerce Website and Marketplace}

The introduction of e-commerce shifts people's buying behaviour from physical shopping to online shopping. According to Turban, E. and King, e-commerce is the mechanism through which goods, services and information are purchased, sold or exchanged, primarily through computer networks, the Internet and intranets. E-commerce can be done throughout the time and location by anyone with a connection. Electronic commerce can be either Business-to-Business (B2B) or Business-to-Consumer (B2C).

Electronic marketplaces or known as a marketplace in this research, are multi-dimensional platforms that share price and product availability details with participating buyers and sellers in specific markets. As such, three players are involved in marketplaces: retailers and consumers, as the stakeholders between whom the trade takes place and the third party, is the marketplace itself (Yul Lee, Kim and Fan, 2013). According to Turban, E. and King, an e-marketplace is a virtual area where buyers and sellers meet and perform various transactions. The E-Marketplace is also known as a digital market where buyers and suppliers gather information about goods and service offerings and negotiate and execute business transactions.

\subsection{Online Convenience}

Online convenience measures how online shoppers can search for goods and compare prices without physically visiting many stores to find products they want. According to Almarashded et al. (2019), shoppers consider the search drawback a primary barrier to effective and easy online shopping. Since customers spend less time shopping and more time on other activities, their desire for convenience has increased, and their interest is therefore focused on internet shopping (Kumar and Kashyap, 2018).

\subsection{Affordability}

When someone shops, price, along with several other factors, are the first thing frequently noticed. Appropriate and acceptable prices for a product shall be required. As per Yan, in 2018, online platforms offer buyers the ability to compare the pricing of different vendors' products without having to go from one store to another before taking their purchase decision. However, in consumer decision-making, the primary role remains pricing (Amati, 2020). Amati (2020) said that research has proven that prices are always an essential issue in the decision making of buyers.

\subsection{Information Quality}

The information quality refers to the consumer's judgment that a final purchasing choice is easy to compare competing products and services. Kotler and Keller (2012) employed many product attributes, including designing the products, quality, packaging design and research model features. The results showed that product features like product information, quality, and prices positively affected the intention to purchase. The product information revealed by Hwangbo et al. (2017) was the benefits and importance of understanding that creates and most utilizes customer interests.

\subsection{Evaluation for Options}

Evaluation for options is the phase in which goods and services are evaluated to each other to determine the best available products. This decision is now entirely subjective, as the choice of consumers differs from one another. Due to the apparent higher variations on online platforms, consumers have more choices. No physical business can provide as much range as an online store does in numerous product categories (Sarkar and Das, 2017). Since internet retailers do not have to worry about space crunch, significant products can be made available at the same site.

\subsection{Promotion}

Promotions are among other marketing actions, which is the most effective marketing strategy. Sales promotion building strong customer' purchasing decisions and impacts their behaviour directly. Strategies of promotions are categorized as pricing and non-price based on nature (Nagadeepa et al., 2015). Some of the price-based promos are money vouchers, reimbursement, rebates and discounts to reduce items costs. Such non-price-based promos are gifts, reward credits or contests that increase value to the product momentarily. 


\subsection{Electronic Word of Mouth (EWOM)}

Electronic word of mouth (eWOM) has contributed a lot in this transformative phase as a technique to consolidate the sharing of consumer sentiments. Emotions are among the most influentially influential aspects in decision-making, according to Ismagilova et al. (2020), and eWOM is highlighted as a crucial means of expressing emotions in virtual situations. Study shows that consumers use eWOM to avoid the danger of purchasing a product available on the Internet. In this perspective, increasing eWOM usage is noted, yet scepticism about advertising initiatives is also growing (Yan et al., 2018).

\subsection{Trusted and Secure}

The perspective of online shoppers towards goods and services are mostly related to the perception of trustworthiness. Consumers tend to purchase an item from a seller they trust or a brand they know (Bojang et al., 2017). Security is defined as the platform's ability to secure personal information from unauthorized information exposure during online transactions and is seen as an essential factor that consumers are perceived to be concerned about (Barusman, 2019). Security and privacy issues play a crucial part in building confidence in online purchases (Aboobucker and Bao, 2018).

\subsection{Value Added Service}

Due to the extreme severe rivalry observed in online markets, simply exposure to good or service catalogues is not enough to ensure the existence of the online business. The focus is on how online retailers deliver individualized services and attention to their customers (Duarte et al., 2018). Internet users want individual attention, better fitted to their demands to cut back on the effort and time needed to find information and providing a purchase choice (Pappas, 2016).

\section{METHODOLOGY}

A qualitative research method is more suitable for this thesis since it explores and defines the factors influencing online shoppers in choosing their preferred online shopping platform. The method is often used to explore, describe, or explain a social phenomenon, which this study aims for. Accordingly, the researcher seeks to achieve this through one-on-one online interviews by allowing the online shoppers to tell individual stories about their shopping experience using their preferred online shopping platform. Consequently, the researcher conducted semi-structured interviews with a sample of Malaysian online shoppers to introduce their ideas and perspectives by referring to the list of questions.

This study aims to identify factors influencing them to shop at e-commerce websites or marketplaces in Malaysia. In this study, four interview questions, each related to respective research questions, are used to conduct the open-ended interviews. A total of 15 online shoppers ranging from 22 to 26 years who contributed to online shopping have agreed to be interviewed. The following interview questions were intended to explore the research question:

a) Do you prefer to shop at marketplace or e-commerce websites?

b) Why?

c) If you were to choose one marketplace or e-commerce website, which one would you choose?

d) Why?

\section{FINDINGS}

A qualitative content analysis was the method used to analyse the information. Each response was compared to another showing the similarities and differences. The responses to each question were analysed and grouped into sections according to questions to display findings easily. Table 1 shows the summary of the themes and indicators obtained from the interviews with the respondents and figure 1 shows the degree of influence each factor on influencing online shopping among online shoppers in Malaysia. It is found that value added service gives the highest influence to the online consumers because of the fix customer service, flexibility, ability to return and refund order, competitive prices and quality, payment using e-wallet, easy to track orders, easy to chat with seller and quick response, fast shipping and provide transparency of the product followed by the online convenience factor. 
Table 1: Summary of Themes and the Indicators Based On the Findings.

\begin{tabular}{|c|c|}
\hline Themes & Indicators \\
\hline Online convenience & $\begin{array}{l}\text { "Simplicity of the feature" } \\
\text { "Easy to browse" } \\
\text { "Easy to choose from favourite brand" } \\
\text { "Save time to checkout" } \\
\text { "Easy access anytime" } \\
\text { "Prices are cheaper" } \\
\text { "Easy to search products" } \\
\text { "Easy to use" } \\
\text { "Hassle-free" } \\
\text { "Wide range of categories" } \\
\text { "Pleasing to eyes" } \\
\text { "Everything in a place" } \\
\text { "User friendly" } \\
\text { "Able to buy many items in one time purchase" } \\
\text { "Can be accessed through mobile apps" } \\
\text { "Can buy from different sellers" } \\
\text { "Easy purchase process" } \\
\text { "Aesthetic web design" }\end{array}$ \\
\hline Affordability & $\begin{array}{l}\text { "More affordable" } \\
\text { "Prices are cheaper" } \\
\text { "Many cheap items" }\end{array}$ \\
\hline Information quality & $\begin{array}{l}\text { "Clear description" } \\
\text { "Can check the stock availability and variety of design" }\end{array}$ \\
\hline $\begin{array}{l}\text { Evaluation for } \\
\text { options }\end{array}$ & $\begin{array}{l}\text { "Focused options" } \\
\text { "Does not mix with other brand" } \\
\text { "Many options to choose from" } \\
\text { "More choices" } \\
\text { "Can choose delivery service" } \\
\text { "Many varieties" } \\
\text { "Can buy new product" } \\
\text { "Variety brands" } \\
\text { "Direct survey for price range option of the same item" }\end{array}$ \\
\hline Promotion & $\begin{array}{l}\text { "Credit store available" } \\
\text { "Can see offers or discounts from the brand" } \\
\text { "Provide the best promotion during sales" } \\
\text { "Can get discount" } \\
\text { "Can get free shipping" } \\
\text { "Offer cashback, promotions and discounts" } \\
\text { "Able to gain benefits such as vouchers and free shipping" } \\
\text { "Able to redeem coins" } \\
\text { "Can collect points or coins for every purchases" }\end{array}$ \\
\hline
\end{tabular}




\begin{tabular}{|c|c|}
\hline $\begin{array}{l}\text { Electronic Word of } \\
\text { Mouth (eWOM) }\end{array}$ & $\begin{array}{l}\text { "Many reviews" } \\
\text { "Can compare customer experience through review" } \\
\text { "Can compare quality through review and product description" } \\
\text { "Many feedback where we can read and decide before buying" } \\
\text { "Able to see feedback from other buyers" }\end{array}$ \\
\hline Trusted and Secure & $\begin{array}{l}\text { "Brand-directed" } \\
\text { "Trusted" } \\
\text { "Easy to refund, return and cancel order" } \\
\text { "Secure" } \\
\text { "More convinced" } \\
\text { "No doubt about the } \\
\text { "No doubt on the quality" } \\
\text { "Secure for defect and lost items" }\end{array}$ \\
\hline Value Added Service & $\begin{array}{l}\text { "Fix customer service" } \\
\text { "Flexibility" } \\
\text { "Easy to return" } \\
\text { "Easy to compare price" } \\
\text { "Easy to return, refund and cancel order" } \\
\text { "Payment using e-wallet" } \\
\text { "Easy to chat with seller" } \\
\text { "Easy to track orders" } \\
\text { "Don't have to worry and wait for the delivery" } \\
\text { "Fast shipping" } \\
\text { "Ability to direct deal with business owner" } \\
\text { "Quick response from seller" } \\
\text { "Competitive prices and quality" } \\
\text { "Provide transparency of the product" }\end{array}$ \\
\hline
\end{tabular}

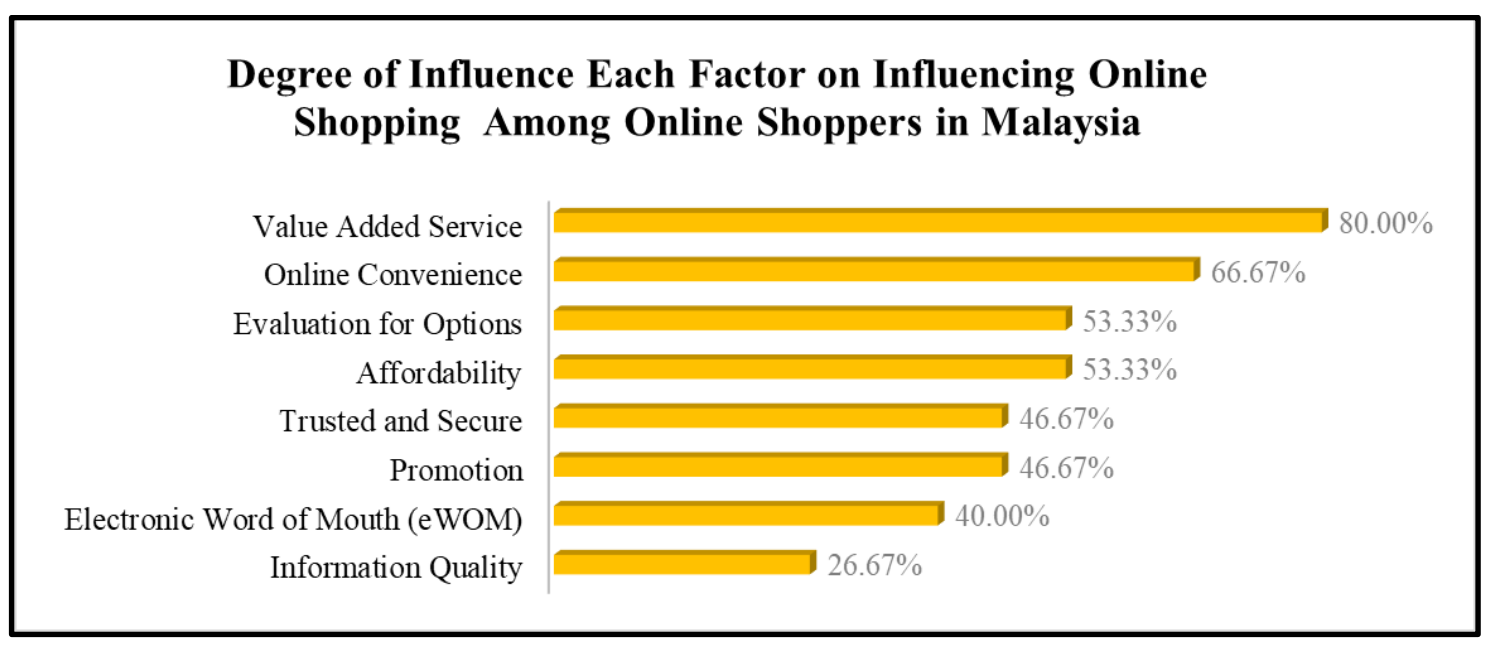

Figure 1: A Chart of the Degree of Influence Each Factor on Influencing Online Shopping Among Online Shoppers in Malaysia. 


\section{CONCLUSION AND DISCUSSION}

This study examines the factors influencing online shoppers to shop at marketplace or website in Malaysia, specifically around Klang Valley. Based on the interview transcripts, the findings support the factors that were obtained from the literature review, mainly online convenience, evaluation for options, promotions, eWOM, trusted and secure, and value added service. As per result, most people prefer the online marketplace to e-commerce websites.

The online convenience of consumers can be felt by having a product search or by giving them conveniences such as being able to open the web and purchase the product or service anytime. Also, payments can be carried out, and the consumer can feel comfortable when the items or the desiring product is purchased online. If internet buying is increasingly easy or convenient, the consumers will also be allowed to save their time. Marza et al. (2019) support this online convenience finding, indicating that online convenience substantially influences the intention to shop online.

With the significant advancement of digital, web and mobile applications, users have obtained uncontrolled access to information about products and brands to choose from at very competitive pricing. Price is also one of the measures consumers emphasized while online shopping, where prices influence consumer product or service judgements. Lower prices can drive online buyers to purchase online (Balachandran et al., 2020).

The information quality on the online retail site provided by the company is equally crucial. A business presence online enables consumers to learn more about the items and services they want. Consumers emphasize the usage of the information on websites because they can compare prices and the quality of the products and services before deciding or searching for cheaper alternatives. One particular research showed that information quality affects consumer internet shopping and loyalty (Putri and Pujani, 2019).

With a growing number of online businesses offering different possibilities, buyers can explore options or selections before making final purchasing choices. Precise and complete information on product descriptions, product availability and prices is needed. This information enables consumers to compare and assess different products, enhancing customer satisfaction and contributing to online shopping intentions (Usman and Anshorulloh, 2019). Multimedia presentations, product or service reviews and customer feedback are all tools that consumers appreciate.

Promotion such as cashback, free shipping, discounts and vouchers will help customers maximize their purchase's utility, efficiency or value for money and provide enjoyment, entertainment or self-esteem. If the promotional price is high, it makes consumers save more, making them more likely to buy goods or services (Tzeng et al., 2021). Previous research has also demonstrated the critical impact of customer buying decisions on sales promotion through discounts and cost reduction (Gorji and Siami, 2020).

This study indicated that customers use eWOM by searching for relevant information before making a purchasing choice. In order to help other users, online users like to develop and share product information. Internet users trust other customer reviews and recommendations before purchasing (He et al., 2020). Sulthana and Vasantha (2019) have found that knowledge sharing in social media through eWOM has a favourable effect on buying purposes.

Consumer trust is the result of the considered safety and privacy of online shopping processes by consumers. Security is one of the essential qualities people want to secure their personal information when online buying. The absence of the website's security and privacy will make consumer trust one of the drawbacks of online purchasing and impede the growth of internet shopping (Wong et al., 2019). In a study from Varma et al. (2020), safety is a crucial issue and one of the most crucial factors for online consumers, whether they are successful or not.

Since online comparison prices are much more accessible, online consumers anticipate high-quality standards; hence online service quality plays a vital role. This finding complements a study by Kasuma et al. (2020), which indicated that the quality of service has a favourable and significant effect on the intention of purchasing. An organization can enhance its competitive advantage over other enterprises through the sale of value-added products and services.

The result of research could help to understand the relationship between online convenience, affordability, information quality, evaluation for options, promotions, eWOM, trusted and secure, and value-added services with online shoppers in Malaysia. The outcomes of this study will help establish theoretical frameworks on how marketplace and e-commerce websites adoption can be fostered through factors impacting acceptance and use of new technology and the cultural characteristics of people. This research will also help an in-depth knowledge of the usage of technology and the cultural 
aspects in the marketplace setting. This study is also expected to be essential for companies who use or plan to sell their products or services on the marketplace or e-commerce websites. This study also helps to understand better different aspects affecting the use of the marketplace and online webpage for future scholars and diverse commercial and government groups. In addition, this study will drive government and businesses to understand consumers' wants, goals, beliefs, and anxieties to deliver better solutions

\section{REFERENCES}

Aboobucker, I., \& Bao, Y. (2018). What obstruct customer acceptance of internet banking? Security and privacy, risk, trust and website usability and the role of moderators. The Journal of High Technology Management Research, 29(1), 109-123.

Almarashdeh, I., Jaradat, G., Abuhamdah, A., Alsmadi, M., Alazzam, M. B. Alkhasawneh, R., \& Awawdeh, I. (2019). The difference between shopping online using mobile apps and website shopping: A case study of service convenience. International Journal of Computer Information Systems and Industrial Management Applications, 11, 151-160.

Amati, M. (2020). The impact of sales promotion, convenience, and service quality on online shopping toward consumers buying decision: Case study of Lazada.

Balachandran, N., Anusree, S. L., \& Balasubramanian, P. (2020). A Study on the Impact of Online Shopping on Organic Food Products in Kochi. JAC: A Journal of Composition Theory, 13(Vi), 111-120.

Barusman, A. R. P. (2019). The Effect of Security, Service Quality, Operations and Information Management, Reliability \& Trustworthiness on E-Loyalty Moderated by Customer Satisfaction on the Online Shopping Website. International Journal Of Supply Chain Management, 8(6), 586594.

Bojang, I., Medvedev, M. A., Spasov, K. B., \& Matvevnina, A. I. (2017, December). Determinants of trust in B2C ecommerce and their relationship with consumer online p. 020001). AIP Publishing LLC. trust. In AIP Conference Proceedings (Vol. 1910, No. 1,

Chevalier, S. (2021). Global retail e-commerce market size 2014-2023. Statista. Retrieve from https://www.statista.com/statistics/379046/worldwide retail-e-commerce-sales/

Duarte, P., e Silva, S. C., \& Ferreira, M. B. (2018). How convenient is it? Delivering online shopping convenience to enhance customer satisfaction and encourage eWOM. Journal of Retailing and Consumer Services, 44, 161-169.

Gorji, M., \& Siami, S. (2020). How sales promotion display affects customer shopping intentions in retails. International Journal of Retail \& Distribution Management.

He, J., Wang, X., Vandenbosch, M. B., \& Nault, B. R. (2020). Revealed preference in online reviews: Purchase verification in the tablet market. Decision Support Systems, 132, 113281.

Hwangbo, H., Kim, Y. S., \& Cha, K. J. (2017). Use of the smart store for persuasive marketing and immersive customer experiences: A case study of Korean apparel enterprise. Mobile Information Systems, 2017

Ismagilova, E., Dwivedi, Y. K., \& Slade, E. (2020). Perceived helpfulness of eWOM: Emotions, fairness and rationality. Journal of Retailing and Consumer Services, 53, 101748.

Jaafar, S. (2020). Over two-thirds of Malaysians now more comfortable shopping online after Covid-19 StanChart. The Edge Markets. Retrieved from https://www.theedgemarkets.com/article/over-twothirds malaysians-now more comfortable-shopping-online-after-covid19-\%E2\%80\%94-stanchart.

Kasuma, J., Kanyan, A., Khairol, M., Sa'ait, N., \& Panit, G. (2020). Factors Influencing Customers Intention for Online Shopping'. International Journal of Modern Trends in Business Research, 3(11), 31-41.

Kotler, P., Keller, K., Ang, S., Leong, S., \& Tan, C. (2012). Marketing Management: An Asian Perspective (6 ${ }^{\text {th }} \quad$ ed., p. 416). Singapore: Pearson.

Kumar, A., \& Kashyap, A. K. (2018). Leveraging utilitarian perspective of online shopping to motivate online shoppers. International Journal of Retail \& Distribution Management.

Marza, S., Idris, I., \& Abror, A. (2019, April). The influence of convenience, enjoyment, perceived risk, and trust on the attitude toward online shopping. In Proceedings ofthe 2nd Padang International Conference on Education, Economics, Business and Accounting (PICEEBA-2 2018), Advances in Economics, Business and Management Research (Vol. 64, pp. 588-597).

Müller, J. (2021, April 7). Malaysia: GMV e-commerce market 2015-2025. Statista.Retrieved from 
https://www.statista.com/statistics/1117638/malaysia gmv-ecommerce-market/.

Nagadeepa, J. Tamil Selvi, Pushpa A. "Impact of Sales Promotion Techniques on Consumers' Impulse Buying Behavior toward Apparels at Bangalore", Asian Journal of Management Sciences \& Education, Vol. $\quad 4(1)$ January 2015.

Pappas, N. (2016). Marketing strategies, perceived risks, and consumer trust in online buying behaviour. Journal of retailing and consumer services, 29, 92-103.

Putri, W. K., \& Pujani, V. (2019). The influence of system quality, information quality, e service quality and perceived value on Shopee consumer loyalty in Padang City. The International Technology Management Review, 8(1), 10-15.

Sarkar, R., \& Das, S. (2017). Online shopping vs Offline shopping: A comparative study. International Journal of Scientific Research in Sience and Tehnology, 3(1).

Sulthana, A. N., \& Vasantha, S. (2019). Influence of electronic word of mouth ewom on purchase intention. International Journal of Scientific \& Technology Research, 8(10), 1-5.

Tzeng, S. Y., Ertz, M., Jo, M. S., \& Sarigöllü, E. (2021). Factors affecting customer satisfaction on online shopping holiday. Marketing Intelligence \& Planning.

Usman, O., \& Anshorulloh, A. (2019). Effect of Customer Satisfaction, Trust, Price and Quality Service on Repurchase Interests in Online Shop. Trust, Price And Quality Service on Repurchase Interests in Online Shop (December 31, 2019).

Varma, M., Kumar, V., Sangvikar, B., and Pawar, A.(2020). Impact of Social Media, Security Risks and Reputation of E-Retailer on Consumer Buying Intentions through Trust in Online Buying: A Structural Equation Modeling Approach. Journal of Critical Reviews, 7(1), 119-127.

Wong, W. P. M., Tan, K. L., Ida, A.K., \& Lim, B.C.Y. (2019). The Effect of Technology Trust on Customer E Loyalty in Online Shopping and the Mediating Effect of Trustworthiness. Journal of Marketing Advances and Practices $1.2 \quad$ (2019): 38-51.

Yan, Q., Wu, S., Zhou, Y., \& Zhang, L. (2018). How differences in eWOM platforms impact consumers' perceptions and decision-making. Journal of Organizational Computing and Electronic Commerce, 28(4), 315-333.

Yul Lee, J., Kim, J. in, and Fan, Q. (2013). The impact of web site quality on flow relatedonline shopping behaviors in C2C e- marketplaces: A cross- national study. Managing Service Quality: an International

Journal, 23(5), 364387. 